\title{
粒子法による多段階ズーミング津波解析に 向けたマトリックスアレイ状の仮想造波板
}

\author{
宮川 欣也 1 ・浅井 光輝 2 \\ 1学生会員 九州大学大学院 工学府建設システム工学専攻（†819-0395 福岡市西区元岡744） \\ E-mail:y_miyagawa@doc.kyushu-u.ac.jp \\ 2正会員 九州大学准教授 工学研究院社会基盤部門（干819-0395 福岡市西区元岡744） \\ E-mail:asai@doc.kyushu-u.ac.jp
}

\begin{abstract}
2011年の東北地方での津波被害以降，今後危惧される巨大地震に伴う津波に対する防災・減災の検討に おける一手段として，津波被害予測シミュレーションの高度化・高精度化が期待されている. 津波解析の 実務の現状としては，主に津波高や津波到達時間を予測することを目的とし，浅水長波の仮定を設けた平 面2次元津波解析が用いられていることが多い。しかしながら, 被害予測までを念頭に置くと津波遡上後 の3次元性が卓越する状態までを解析することが要求されるため，ナビエ・ストークス方程式に準じた 3 次元津波解析を実施することが望ましい。 そこで，差分法などによる平面2次元津波解析と 3 次元津波解析 を連動することで，広範囲の津波伝搬予測に裏付けられた流入条件により，津波遡上現象を3次元で予測 する試みが行われている。本論文では，3次元津波遡上解析を粒子法にて行うことにし，平面 2 次元津波解 析結果, あるいは観測データなどの情報から, 遡上域での3次元津波ズーミング解析を実施する際に有効 となるマトリックスアレイ状仮想造波板境界処理法を提案した。
\end{abstract}

Key Words : Tsunami, Particle method, Virtual wave-making plate, multi-zooming

\section{1. 緒言}

2011年3月11日に発生した東北地方太平洋沖地震に伴 う津波により，太平洋沿岸地域の多くの土木構造物に甚 大な被害が発生した. 震災から数年が経過した現在, 南 海トラフ地震をはじめとする，今後危惧される巨大地震 に伴う津波に対して，沿岸地域の防災・減災が積極的に 議論されている．特に，震源から浸水域といら広範囲に わたる津波被害に対しては，大規模津波シミュレーショ ンを構造物の被害予測に活用することは有効な手段であ るといえる.

広域性を有する津波被害予測を効率的に行うため，震 源から沿岸海域までの2次元解析と遡上域の3次元解析を 組み合わせたズーミング津波解析がこれまで提案されて きた ${ }^{12)}$. 本研究では, 広域の2次元解析は浅水長波理論 に基づいた2次元差分法, 湾口から遡上域および構造物 周辺の流れは3次元粒子法にて解析するものとし，これ らを段階的にズーミング解析するための境界処理方法を 提案する．なお， 3次元解析手法として粒子法を採用寸 ることで，建物群を含む複雑な地形モデルの作成が容易 となる，また建物周辺での形状変化の激しい波まで3次
元解析が可能となるなどの利点が期待できる.

2次元差分法と 3次元粒子法を連成した津波解析を行っ た例としては，室谷ら゙にとよるMPS法を用いた津波浸水

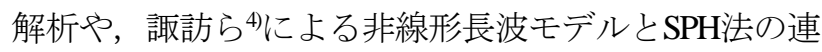
成シミュレーションがある. 3次元津波解析の流入条件 を付与する際，両者は2次元津波解析より得られる断面 平均流速と波高を用い，津波の流入，流出を入力してい る. 本論文では上記の断面平均流速を用いて一様に流入 させる手法を従来法と参照する. 従来法は, 水深方向に 流速分布が存在しないという浅水長波の成立する領域で の連成において，有効なものと考えられるものの，津波 遡上解析から構造物周辺流れまでを対象としズーミング 解析する際には，もはや浅水長波の仮定が繳密には満足 することができず，より柔軟な流入・流出境界処理法を 開発する必要がある.

上記の問題に対し, 柴田ら 子を局所的に重祮合わせて計算する重合粒子法を提案し ている. この手法では, 解像度の粗い粒子法から, 細か い粒子法へと一方向5，あるいは双方向のに解析条件を受 け渡す方法であり, 現状では質量保存と運動量保存が厳 密に満たすことが困難と報告されている，そこで，本研 
究では粒子法による多段階ズーミング津波解析における 流入・流出境界処理法として, 新たにマトリックスアレ イ状の仮想造波板を提案し，これまで用いられてきた従 来法とズーミング前後のエネルギー収支関係を比較する ことにより，提案手法の有用性を確認する.

\section{2. 多段階ズーミング解析}

一般的に津波の数值解析手法としては, 浅水長波理論 に基づく2次元津波解析と， Navier-Stokes式を直接解く 3 次元津波解析に大きく分けることができる. 2次元津波 解析の特徽としては, 震源から海岸までの津波の伝播を 予測する際, 2次元化による計算コストの小ささから, 比較的短時間に解析を行える点において有用であり, 従 来，津波浸水高や津波到達時間を予測する際に用いられ ている. しかしながらこの手法は，（浅水長波の仮定を 用いることのできる）高さ方向の流速を無視できる領域 では有効であるものの，陸上に遡上し，地形の起伏が激 しい場合や，砕波などの複雑な波等の詳細な津波の浸水 状況などを予測することは困難である．また，圧力を静 水圧より導出することから, 構造物に作用する衝撃的な 津波流体力を正確に推定寸ることは不可能である. 一方, 3次元津波解析は2次元津波解析の持つ圧力等の問題を解 決できるといった利点があるが，計算コストでの制約が 大きく, 震源からの津波伝播解析を行うことは現実的で はない，そこで本研究では，両者の利点を活かし，震源 から湾口までの津波伝播解析（レベル0解析）を2次元差 分法, 湾口から内陸までの津波遡上解析 (レベル1解 析）と構造物周辺流れの解析（レベル2解析）を3次元粒 子法で解析を行うこととする（図-1を参照）。またここ では，2段階のズーミング解析を述べたが，必要に応じ， 更なる多段階のズーミング解析も可能である.

\section{3. 解析手法}

\section{(1) SPH法の基礎}

SPH法は粒子法の一つであり, 圧縮性流体の解析手法 として提案されたのちに, 非压縮性流体解析法(ISPH法) へと拡張された。まずSPH法では任意の空間点 $\boldsymbol{x}$ におい て定義される時刻 $t$ でのスカラー関数 $\phi(x, t)$ が, 次式に 示寸積分形式として近似される.

$$
\phi(\boldsymbol{x}, t) \approx \int_{V} W\left(\left|\boldsymbol{x}-\boldsymbol{x}^{\prime}\right|, h\right) \phi\left(\boldsymbol{x}^{\prime}, t\right) d V
$$

ここで, $W$ はカーネル関数と呼ばれる一種の重み関数 であり，SPH法では一般的にはその近似として影響半径 $h$ 内でのみ非ゼロ正值となるコンパクトサポートな関数 かつUnity条件を満足する関数を用いている. 上式で示

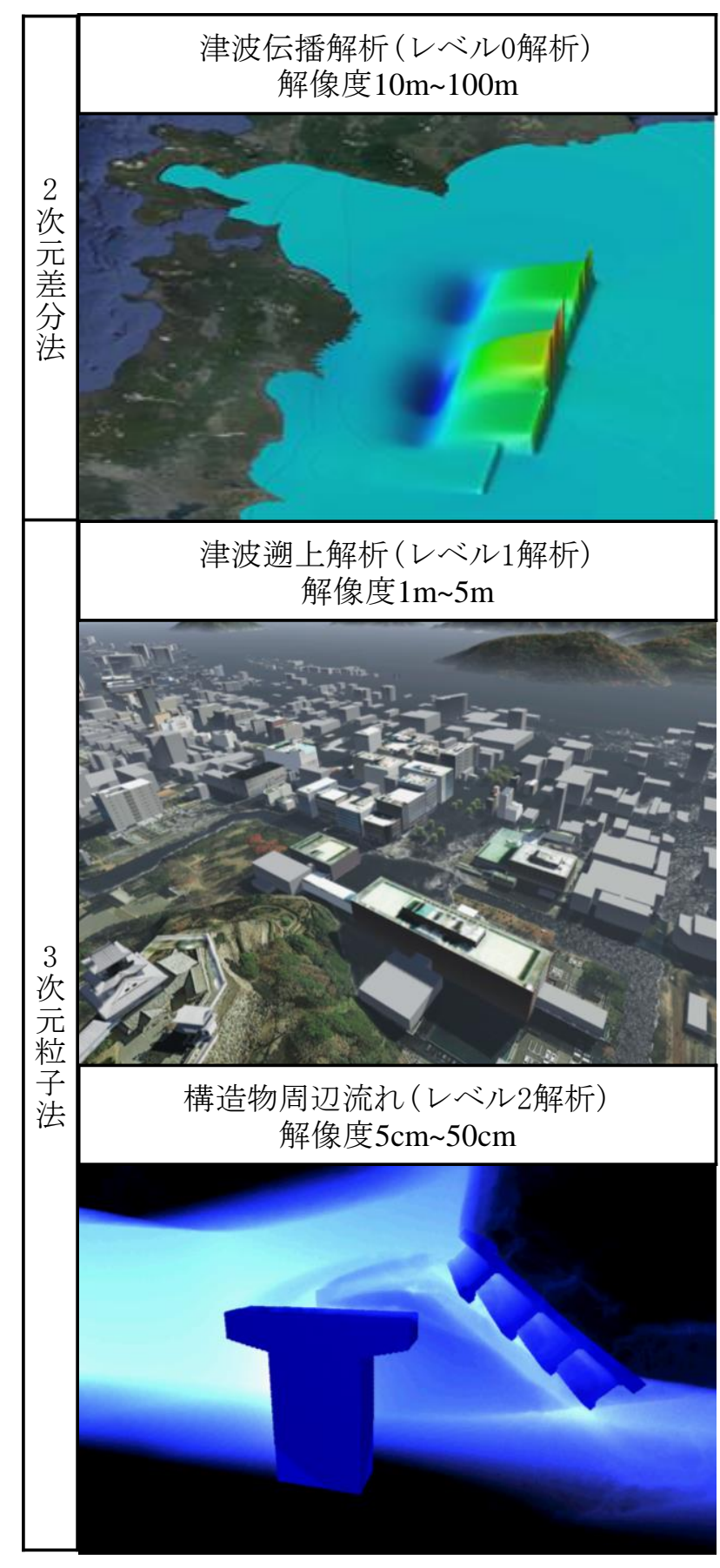

図-1 多段階ズーミング解析の概要

した積分は，空間上に分布する粒子 $\boldsymbol{x}_{i}$ を用いて離散化 を行い, 影響半径 $h$ 内に含まれる近傍粒子の值を用いた 重み付き総和によって近似できる.

$$
\phi\left(\boldsymbol{x}_{i}, t\right) \approx\left\langle\phi_{i}\right\rangle=\sum_{j} \frac{m_{j}}{\rho_{j}} W\left(r_{i j}, h\right) \phi_{j}\left(\boldsymbol{x}_{j}, t\right)
$$

ここで，下付き添え字 $i, j$ は粒子番号を示し $, \rho_{j}, m_{j}$ は それぞれ粒子 $j$ が代表する近傍領域の密度と質量とする。 また, $r_{i j}=\left(\left|\boldsymbol{x}_{i}-\boldsymbol{x}_{j}\right|\right)$ は評価点と近傍粒子との距離関数 を示し, 〈·〉が付いた関数は上記に示したSPH法による 
近似值であるものとする.

関数の勾配はSPH法の近似式(2)を微分することで評価

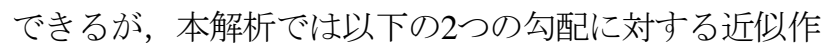
用素を採用寸る.

$$
\begin{aligned}
& \left\langle\nabla \phi_{i}\right\rangle=\frac{1}{\rho_{i}} \sum_{j} m_{j}\left(\phi_{j}-\phi_{i}\right) \nabla W\left(r_{i j}, h\right) \\
& \left\langle\nabla \phi_{i}\right\rangle=\rho_{i} \sum_{j} m_{j}\left(\frac{\phi_{j}}{\rho_{j}^{2}}+\frac{\phi_{i}}{\rho_{i}^{2}}\right) \nabla W\left(r_{i j}, h\right)
\end{aligned}
$$

また，関数のラプラシアンは以下のものを採用する.

$$
\left\langle\nabla^{2} \phi_{i}\right\rangle=\sum_{j} m_{j}\left(\frac{\rho_{i}+\rho_{j}}{\rho_{i} \rho_{j}} \frac{\boldsymbol{r}_{i j} \nabla W\left(r_{i j}, h\right)}{\boldsymbol{r}_{i j}^{2}+\eta^{2}}\right)\left(\phi_{i}-\phi_{j}\right)
$$

ここで，式(5)中の $\eta$ はゼロ割を避けるための安定化パラ メータであり, 文献りに習って影響半径 $h$ を参照し $\eta^{2}$ $=0.0001 h^{2}$ 与えることにした，なお，本研究では重み関 数に3次のスプライン関数を用い, 影響半径 $h$ は初期粒子 間隔の2.4倍としている8.

\section{（2）非圧縮性流体の支配方程式とその粒子離散化}

非圧縮性流体問題では，質量と運動量の保存則を満足 するように，流速 $\boldsymbol{u}$, 圧力 $p$ を求める. ラグランジュ記 述によれば2つの保存則は次式により記述できる.

$$
\begin{gathered}
\frac{D \rho}{D t}+\rho \nabla \cdot \boldsymbol{u}=0 \\
\frac{D \boldsymbol{u}}{D t}=-\frac{1}{\rho} \nabla p+\underbrace{V \nabla^{2} \boldsymbol{u}+\boldsymbol{g}}_{f}
\end{gathered}
$$

ここで， vは動粘性係数を示し， $\mathrm{g}, \boldsymbol{f}$ はそれぞれ重力加 速度, 重力加速度に粘性力を加えたベクトルとする。

非压縮性の仮定より密度が一定とすれば，質量保存則 (6)は以下のように書き換えられる.

$$
\nabla \cdot \boldsymbol{u}=0
$$

非圧縮性を仮定し，式(2)から式(7)に対応した粒子離 散近似を代入すると，粒子 $i$ において式(6)，(7)は以下の ように近似できる.

$$
\begin{gathered}
\left\langle\nabla \cdot \boldsymbol{u}_{i}\right\rangle \approx 0 \\
\frac{D \boldsymbol{u}_{i}}{D t} \approx-\frac{1}{\rho_{i}}\left\langle\nabla p_{i}\right\rangle+v\left\langle\nabla^{2} \boldsymbol{u}_{i}\right\rangle+\boldsymbol{g}_{i}
\end{gathered}
$$

ここで, 式(10)の右辺第1項は式(4)における関数 $\phi$ に圧力 $p$ を代入すればそのまま評価でき，第2項については式(5) の $\phi$ に $\boldsymbol{u}$ を代入すればよい.

\section{（3）ISPH法}

射影法を用いれば，ナビエ・ストークス方程式の圧力 勾配項を無視した仮の状態を定義することで速度と圧力 が分離でき，速度は陽的に圧力については陰的に更新す る9.これはMPS法と同じ手順であり，SPH法に射影法 を適用した手法をISPH法として参照する.

時間ステップ $n$ から $n+1$ における変数の更新手順を示 す.まずは, 式(7)中の時間微分項を前進差分近似する ものとし，ある中間状態での速度 $\boldsymbol{u}^{*}$ を定義することで 速度を以下のように分離する。

$$
\frac{D \boldsymbol{u}}{D t}=\frac{\boldsymbol{u}^{n+1}-\boldsymbol{u}^{n}}{\Delta t}=\frac{\boldsymbol{u}^{n+1}-\boldsymbol{u}^{*}}{\Delta t}+\frac{\boldsymbol{u}^{*}-\boldsymbol{u}^{n}}{\Delta t}
$$

分離後の加速度成分の内, 前者が式(7)中の圧力勾配項 に, 後者はそれ以外の項に対応寸るものとすることで, 次のように仮の中間状態での速度 $\boldsymbol{u}^{*}$ を更新する.

$$
\begin{aligned}
& \frac{\boldsymbol{u}_{i}^{*}-\boldsymbol{u}_{i}^{n}}{D t}=v\left\langle\nabla^{2} \boldsymbol{u}_{i}^{n}\right\rangle+\boldsymbol{g}_{i} \\
& \rightarrow \text { (予測子) } \boldsymbol{u}_{i}^{*}=\boldsymbol{u}_{i}^{n}+\Delta t\left(v\left\langle\nabla^{2} \boldsymbol{u}_{i}^{n}\right\rangle+\boldsymbol{g}_{i}\right)
\end{aligned}
$$

その後, いずれかの方法により圧力值が評価されたも のとすれば，仮の中間状態から次の時間ステップにおけ る速度を以下のように修正する。

$$
\begin{gathered}
\frac{\boldsymbol{u}_{i}^{n+1}-\boldsymbol{u}_{i}^{*}}{\Delta t}=-\frac{1}{\rho}\left\langle\nabla p_{i}^{n+1}\right\rangle \\
\rightarrow \text { (修正子) } \quad \boldsymbol{u}^{n+1}=\boldsymbol{u}^{*}+\Delta \boldsymbol{u}^{*} \\
\Delta \boldsymbol{u}^{*}=-\Delta t\left(\frac{1}{\rho}\left\langle\nabla p_{i}^{n+1}\right\rangle\right)
\end{gathered}
$$

上記の手順における式(12)，(13)はそれぞれ予測子・修正 子計算と呼ばれ，2段階で状態を更新することがISPH法 の特徴である。

なお, 圧力は, 次に示寸圧力ポアソン方程式を解くこ とで評価できる.

$$
\begin{aligned}
\left\langle\nabla^{2} p_{i}^{n+1}\right\rangle & =-\frac{\rho^{0}}{\Delta t}\left\langle\nabla \cdot \Delta \boldsymbol{u}_{i}^{*}\right\rangle \\
& =\frac{\rho^{0}}{\Delta t}\left\langle\nabla \cdot \boldsymbol{u}_{i}^{*}\right\rangle
\end{aligned}
$$

\section{（4）非圧縮条件を緩和したソース項}

SPH法の近似は，粒子が均一に分布しているときに高 精度となり, 空間的な粗密が生じればその精度は低下寸 る. 最近では, この粒子の粗密を回避するために, 上記 の計算ののちに粒子の再配置を行ういわゆるシフティン グが用いられることが多い10). 著者らは上記の圧力ポア 
ソン方程式を解く際に同時に同様の効果が期待できる非 圧縮条件緩和型のソース項を提案した ${ }^{11)}$.

$$
\left\langle\nabla^{2} p_{i}^{n+1}\right\rangle \approx \frac{\rho^{0}}{\Delta t}\left\langle\nabla \cdot \boldsymbol{u}_{i}^{*}\right\rangle+\alpha \frac{\rho_{i}^{0}-\left\langle\rho_{i}^{n}\right\rangle}{\Delta t^{2}}
$$

この圧力ポアソン方程式は, 緩和パラメータをゼロと すれば速度発散ゼロ条件による定式化と完全に一致する。 この定式化によれば，解析上生じる密度に関する累積誤 差に対しては密度差の項で徐々に解消され，長期間の計 算においても密度がほぼ一定に保たれることで体積保存 性の良いスキームとなる。本論文では緩和パラメータを $\alpha=0.01$ と設定した.

\section{（5）仮想マーカーによる境界処理}

著者らは，仮想マーカー境界処理法12)を発展させ，階 段状の実際のなめらかな境界とは一致しない非適合境界 のときにも処理可能な方法として一般化し，任意の3次 元形状に対して，速度に関してはすべり・非すべり条件 を，圧力に関しては式(7)で定義したベクトルfを用い次 式に示寸非一様ノイマン条件

$$
\partial p / \partial \boldsymbol{n}=\rho \boldsymbol{f} \cdot \boldsymbol{n}
$$

を壁面上にて高精度に満足することに成功している13). なお， $\boldsymbol{n}$ は壁の内向き法線ベクトルを示寸．本研究でも， この境界処理法を採用している. 解析手順とその詳細は 文献13を参照していただきたい。

\section{3. マトリックスアレイ状仮想造波板}

多段階ズーミング津波解析を実現するために，ズーミ ング前の低レベルでの解析の定点上において，波高，流 速，および圧力を観測し，より高レベルでのズーミング 解析ではその観測情報を流入条件とする片方向の連成手 法を提案する.

\section{（1） 観測用セル(低レベル解析）・境界処理用セル（高レ ベル解析)の取り扱い}

本研究では，低レベルでの解析結果が得られたものと し，その結果を参照することで高レベルのズーミング解 析を実施する. なお，ズーミング前の低レベルの数值解 析手法は，粒子法に限らず，浅水長波の仮定を用いた平 面 2 次元解析，あるいはその他の数值解析法などとの連 成も念頭においているが，本論文では粒子法一粒子法間 での連成解析を行うものとする．また，粒子法の空間解 像度は両者の連成の際に同じものとする.

ここでズーミング前の低レベル解析において，流れ方

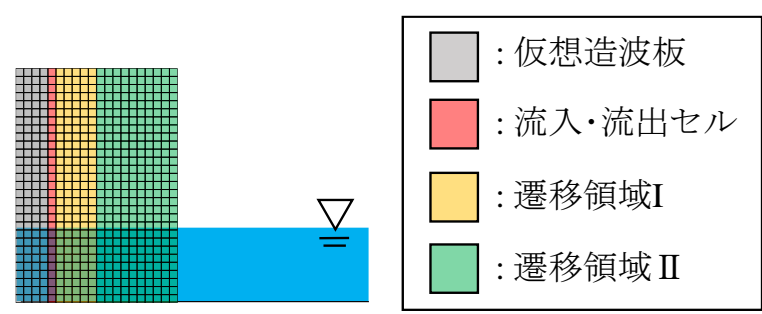

図-2＼cjkstart境界処理用セルの概要



図-3 境界における流入・流出

向に対して，波高，流速，および圧力を観測するセル （以降，観測用セルと略記）を 20 列配置するものとす る.なお，セルの幅はズーミング後解析に用いる粒子間 隔と同じものとする. この観測セル内の水粒子の平均流 速 $\hat{\boldsymbol{v}}$ と平均圧力 $\hat{P}$, 観測点上の波高 $h$ を記録する. この 平均流速，圧力の操作は，SPH 法による内抻近似式(2)を 用いるものとした．またズーミング後の高レベルの粒子 法解析における流入領域は，この観測用セルと同じ領域 とし，流れ方向に 20 列の流入条件付与のためのセル （以降，境界処理用セルと略記）を配置する（図-2 を 参照）。本論文では，境界処理用セルの流入境界端部か ら 5 列は観測した流速を水粒子に与えるための仮想造波 板とした．この仮想造波板では，各セルの中心に粒子が 配置されており，一七ル分だけ主流方向前後へと平行移 動できるセルとしており，初期の境界処理用セルから高 レベル解析側に飛び出した粒子はその後に水粒子として SPH 法の計算により速度場を評価し，逆に流入側に戻っ た粒子は消去することで，流入と流出の両者をコントロ 一ルする (図-3 を参照) 。なお，この流入・流出の判 定には，境界処理用セル先頭に位置する流入・流出セル により，判定することにした（条件は次節にて詳細を説 明）。また境界処理用セルの残りの 15 層は，2 種類の 遷移領域を設定し，仮想造波板前面に 5 列を遷移領域 I を，さらにその先に 10 列を遷移領域川を定義し，その 後の SPH 法による計算へと滑らかに情報（流速・圧 
力）を伝達するものとした（詳細の取り扱いは後述す る) .

\section{（2）仮想造波板における流入・流出の判定}

粒子法は Lagrange 法であるため, 境界における，水の 流入・流出を表現するためには，実際に水粒子を生成， 吸収することが必要となる.この判定は, 仮想造波板先 頭に位置する流入・流出セルにて行うものとした．ここ で，津波などの水平方向の速度が卓越した流れを想定し， その主流方向を $\boldsymbol{n}$ とする．また，造波境界の法線方向は この主流方向 $\boldsymbol{n}$ と同一に設定しているものとすれば, 次 式により水平方向の移動距離 $L$ をえることができる.

$$
L=\sum \boldsymbol{v} \cdot \boldsymbol{n} d t
$$

水粒子を生成, 吸収する際は, この移動距離 $L$ をパラ

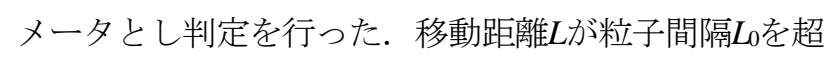
えた場合, 粒子を流入・流出セル上に生成しこの粒子を SPH解析一と放出し, 移動距離が 一 L 0 を下回った場合, 流入・流出セルを超える水粒子を消去することで，水の 流入・流出を表現することとした（図-3を参照）。なお， 仮想造波板の高さは各列ともに同一とし，その高さは先 頭列にある流入・流出セルの位置にて決定するものとし た.この高さは, 低レベルの解析における初期の流入・ 流出位置で計測した波高を用いるもとのし，その経時的 変化を表現するものとした.

\section{（3） マトリックスアレイ状仮想造波板}

本研究では，仮想造波板を構成する粒子は，元の位置 から主流方向 $\boldsymbol{n}$ に一 $L_{0}$ から $L_{0}$ の間を可動域とし，その 移動距離は式(18)により与えられるものとしている。 こ こで，浅水長波の仮定が十分に適用できる領域であれば, 深さ方向一の流速の変動は少なく平均流速と一致するは ずである．しかしながら，一般的には流速は深さ方向に 変動し, また平面内においても流速が分布する. このよ うな状況を踏まえ，この仮想造波板は，水粒子の速度分 布に応じて，各粒子は独立に移動できることにしている， たとえば，水平，および鉛直方向の速度分布を考慮する 場合にはそれぞれ各層, 各列が一様に移動し, 水平およ び鉛直の両方向ともに複雑に流速が分布する場合にはマ トリックスアレイ状に自由に移動することができる（図 -4 を参照）。この仮想造波板をマトリックスアレイ状 仮想造波板として定義する. なおこの造波板は，通常の 物理的な造波板の機能に加えて, 必要に応じて水粒子を 生成する，あるいは吸収する役割を持つものであり，ま たその移動距離は一 $L_{0}$ から $L_{0}$ にのみ限定されているも のであることから，仮想造波板と呼ぶことにした.
全方向一様型（従来法）

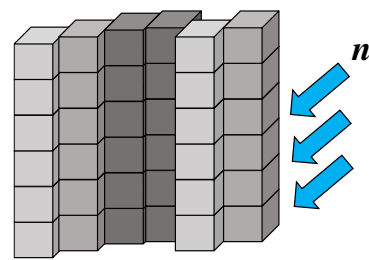

水平方向変動型



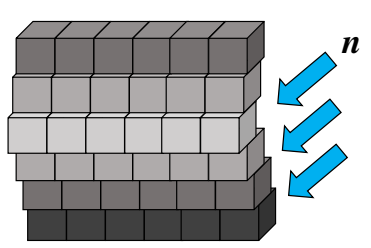

高さ方向変動型

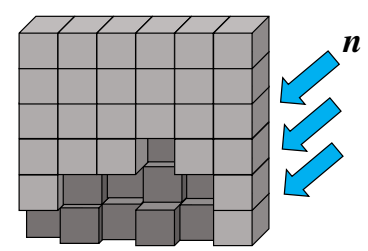

マトリックスアレイ状 図-4＼cjkstart仮想造波板のイメージ

\section{(4) 流入セル内の粒子の速度および圧力評価}

前述のように, 境界処理用セルの端部の5層は仮想造 波板として設定し，一L加らL。の距離で移動する．また， その造波板を形成するセルの中心に位置する粒子は，事 前に実施した低レベルの解析における観測データから， 圧力および速度をそのままマッピングして与えることに した，その先に設定する2種類の遷移領域I，IIでは両者 とも速度と位置の更新について通常のSPH法による計算 により与えるものとするが, 圧力については低レベルで の解析結果を重視することで, 以下に示すように別途マ ッピングする方針とした.

この遷移領域は, ズーミング後の高レベルの数值解析 と事前に行った低レベルの数值解析間での流れの不整合 を解消寸るために設置している，遷移領域 I の圧力はズ ーミング前の低レベルの解析において観測した，セル内

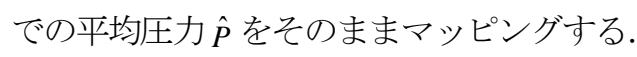

$$
P^{\mathrm{I}}=\hat{P}
$$

次に遷移領域Iでの圧力は, 低レベル解析において観 測された圧力と高レベル解析の数值解析から算出される 圧力を用いて以下の式により与えることとした.

$$
\begin{gathered}
P^{\mathrm{II}}=\beta \hat{P}+(1-\beta)\langle P\rangle \\
\beta=\left(l_{\Pi}-l\right) / l_{\mathrm{II}}
\end{gathered}
$$

ここで $l_{\Pi}$ は遷移領域 $I$ の全長, $は$ は流入・流出セルまでの 距離であり， $\beta(0 \leq \beta \leq 1)$ はセル上の圧力と実際の解 析より求められる圧力を緩和寸るためのパラメータであ る. 


\section{4. 検証例題}

マトリックスアレイ状仮想造波板の有用性を確認する ため，図-5に示す一般的な造波板を用いた斜面遡上問題 を取り上げ，単一解像度による粒子法解析を参照解とし， 仮想造波板を用いた多段階解析の精度を確認した。なお， 検証例題としては，参照解を作成する際の造波板の動き を調整することで特性の異なる2種類の波に対して検証 を行った。はじめの例題は，比較的浅水長波の仮定が成 立する状態のままズーミング解析を実施するように，十 分に遅い速度にて造波させた例を設定した．2つ目の例 題では，造波板を比較的高速に正負に繰り返し移動させ ることで，押し波だけでなく引き波まで発生させ，また 浅水長波の仮定が成立しない状態を作成した。 寸なわち 前者は, レベル0解析（浅水長波）からレベル1解析（粒 子法による3次元解析）へのズーミング解析を想定した 例題であり，後者はより3次元解析間でのズーミングで あるレベル1解析 (粒子法) からレベル2解析 (粒子法) へのズーミング解析を想定した例である.

\section{（1） 長周期波の検証例題（レベル0ーレベル1解析を想定）}

図-5に解析モデルの概要を示す．解析例題は2次元的 な設定となっているものの，水路幅を $3 \mathrm{~m}$ とした 3 次元解 析を実施している。なお，粒子間隔は0.1[m]，時間増分 は0.001[s]，壁面の境界条件はすべり条件とした。ここで は，あらかじめ水槽に水深 $1 \mathrm{~m}$ 水を張り，モデル左端 のピストン型造波板に $x$ 方向速度 $v_{x}=0.5[\mathrm{~m} / \mathrm{s}]$ を 20 秒間与え て $x$ 方向に $10 \mathrm{~m}$ 強制的に変位させることで，比較的長周 期の押し波を生成した。また，事前解析において $x=14.5 \mathrm{~m}$ 地点から観測用セルを20列配置し，観測用セル における流速，圧力，流入・流出セル（15.0m 15.1m） における波高を観測する. 事前解析の後，観測した波高， 圧力，流速を用いて，全方向一様型仮想造波板（図-4を 参照）を用いて断面平均流速による流入境界を従来法と し，提案法としてはマトリックスアレイ状仮想造波板の 一例である高さ方向変動型仮想造波板による境界処理を 行った結果を示し, 参照解（単一の解析結果）と比較検 証を行った。 なお従来法では， $x$ 方向速度として各セル で計測された $x$ 方向流速を高さ方向に平均化した值を用 いる. 各解析の数值解析結果を図-6に示寸. 同図より, 従来法, 提案法ともに参照解の水面形状とよく一致して いることがわかる。

図-7には参照解と従来法，提案法の境界付近の圧力分 布を示す，同図より，断面平均流速のみで境界処理を行 う従来法では，境界付近の水の圧力に多少の振動が見ら れ，瞬間的に圧力が高くなる場合が観測された。一方で， 遷移領域により圧力の境界処理を行う提案法では，圧力

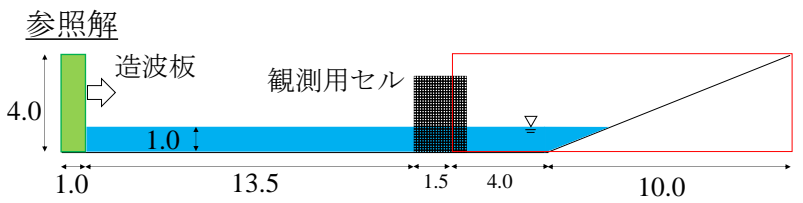

従来法, 提案法



図-5 解析モデル概要

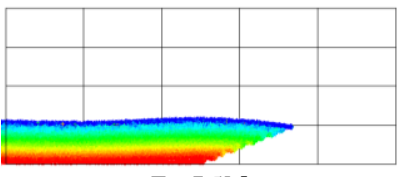

$\mathrm{T}=7.5[\mathrm{~s}]$

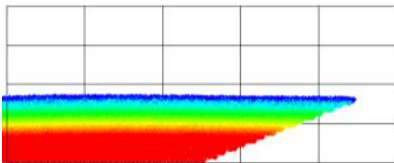

$\mathrm{T}=22.5[\mathrm{~s}]$

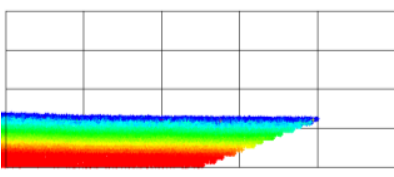

$\mathrm{T}=15.0[\mathrm{~s}]$

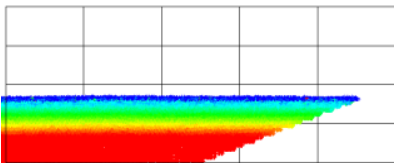

$\mathrm{T}=30.0[\mathrm{~s}]$ (a)参照解における各時間の水面形状

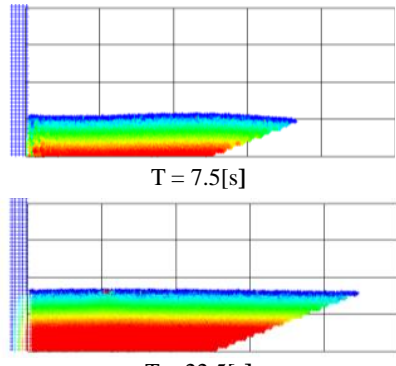

$\mathrm{T}=22.5[\mathrm{~s}]$

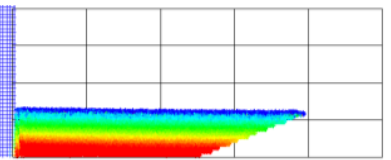

$\mathrm{T}=15.0[\mathrm{~s}]$

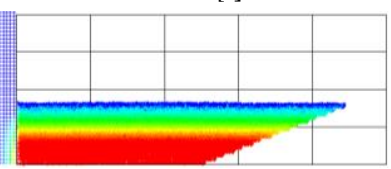

$\mathrm{T}=30.0[\mathrm{~s}]$ (b)従来法における各時間の水面形状

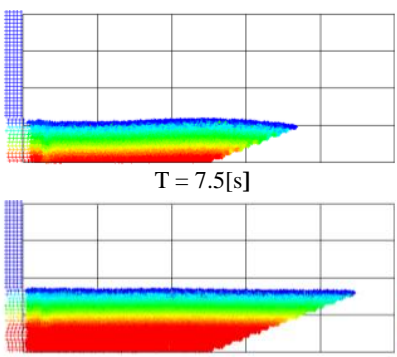

$\mathrm{T}=22.5[\mathrm{~s}]$

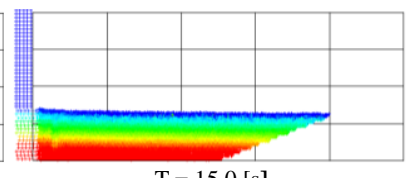
$\mathrm{T}=15.0[\mathrm{~s}]$

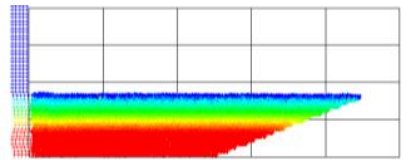

$\mathrm{T}=30.0[\mathrm{~s}]$ (c)提案法における各時間の水面形状

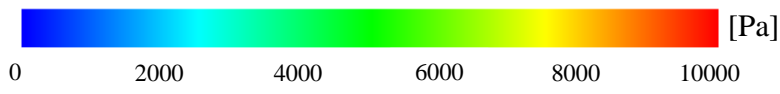

図-6 解析結果（長周期波）（コンター圧力）

の振動はほぼ見られず，なめらかな水粒子の流入を再現 できていることがわかる，次に，解析間でのエネルギー 収支を確認するために，図-5の赤枠で囲まれた領域の水 粒子の全水頭, 粒子数の時刻履歴を比較検証した. 水粒 子の全水頭は以下の式より求めた. 


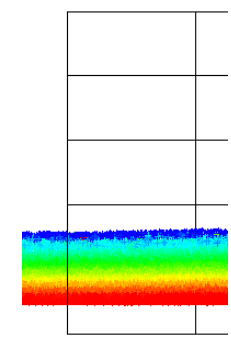

a) 参照解

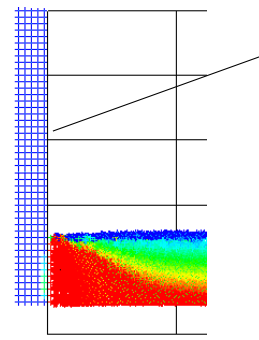

b) 従来法

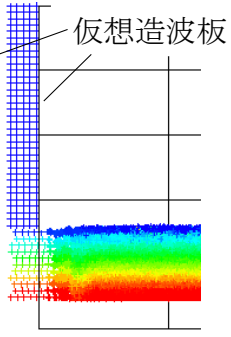

c) 提案法

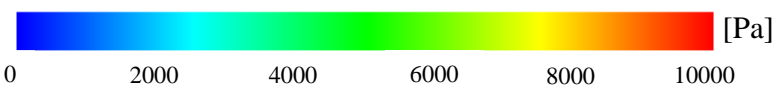

図-7 流入境界付近の圧力分布 $(\mathrm{T}=8.4[\mathrm{~s}])$

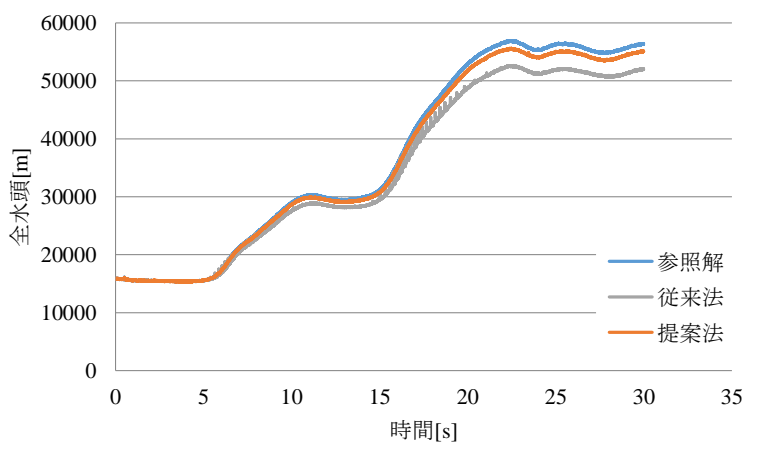

(a)全水頭の時刻変化

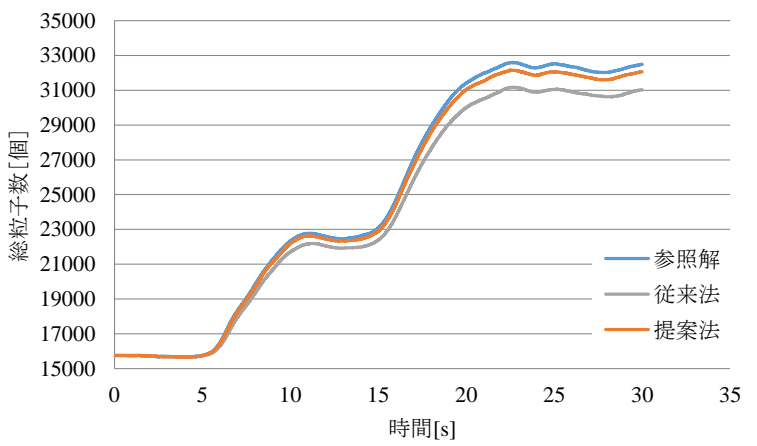

(b)水粒子数の時刻変化

図-8 解析結果 (長周期波)

$$
\text { 全水頭 }=\sum\left(\frac{P}{\rho g}+\frac{v^{2}}{2 g}+h\right)
$$

結果を図-8に示す. 同図より, 提案法と比較して従来 法は参照解との差はみられるものの, 全水頭において最 大でも約-8.5\%の誤差に収まっており，ズーミング前後 の解析間でエネルギー収支がある程度は満足されている ことが確認できた. さらに，深さ方向への速度分布まで を再現できる提案手法では，その䛊差は約-2.8\%程度ま で抑えることができ，その優位性を確認した。

以上の結果から，津波伝搬解析で追うような浅水長波 理論を満足する比較的長周期の波であれば，従来の断面 平均流速を用いた造波板による境界処理でもある程度の 精度で連成することは可能であるが，提案手法により， さらに高精度な連成が可能であることを示した。しかし

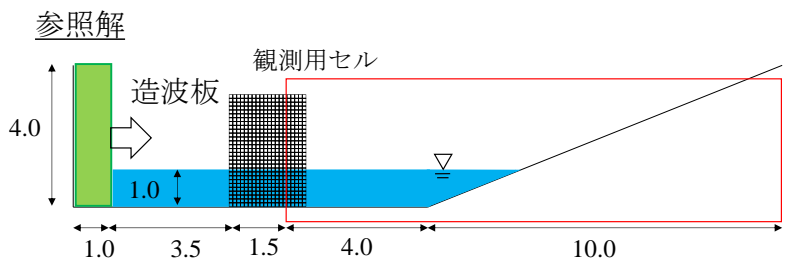

従来法, 提案法

境界処理用セル

奥行き: 3.0 単位 : $\mathrm{m}$

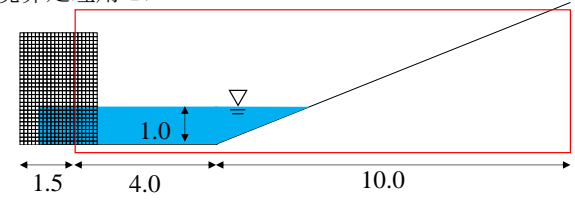

図-9 解析モデル概要

ながら，ここでの検証は押し波のみを考慮したものであ るため，引き波や反射波の影響を受ける第2波の影響に ついては議論できていないことからも，次に示す追加検 証を実施した。

\section{（2）短周期波の検証例題（レベル1ーレベル2解析を想定）}

次に，短周期波の連成時における提案手法の妥当性を 確認するため，図-5と比べ造波板を観測用セルに近づけ たモデルを作成した(図-9). なお前節と同様に，粒子間 隔は0.1[m]，時間増分は0.001[s]，壁面の境界条件はす心゙ り条件とした．本来は，ズーミング解析を想定している ため，ズーミング後の解析における粒子間隔は参照解よ りも小さく設定すべきではあるが，参照解と同じ波を再 現することで境界処理方法の精度を確認する目的のため, 粒子間隔はすべて一致させている。ここでは，ピストン 型造波板に $v_{x}=1.57 \sin \pi t$ を与え, 継続的に変位させ ることで，津波の押し波引き波を簡易的に再現した。 事前解析において,$x=4.5 \mathrm{~m}$ 地点から観測用セルを 20 列 配置し, 観測用セルにおける流速, 圧力, 流入・流出セ ル(5.0m 5.1m)における波高を観測する. その他の解析条 件は前節と同様である.

各解析の任意時間における流速分布の比較を図-10に 示す. 同図より，事前解析でピストン型造波板を用いて 継続的に生成した波は，高さ方向に流速分布を持ち，断 面平均流速を用いた従来法では波形, 流速分布ともに再 現することが困難であることを確認した．特に，境界付 近で引き波が発生する際，境界から流出する水粒子は断 面平均流速で移動する仮想造波板と反発し合い，瞬間的 に圧力が上昇し，水粒子が飛散する様子が確認された

（図-11を参照）。一方で提案手法の一例である高さ方 向変動型仮想造波板を用いた解析では，事前解析で観測 された波形，流速分布をほぼ正確に再現できており，流 入・流出境界付近での圧力の乱れを抑制できていた. 


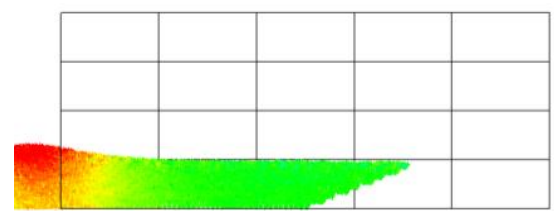

$\mathrm{T}=2.5[\mathrm{~s}]$

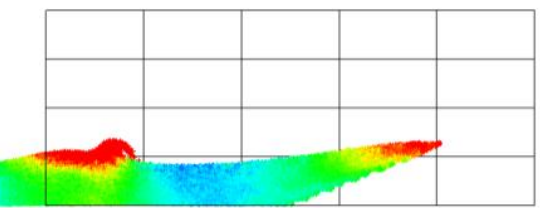

$\mathrm{T}=5.0[\mathrm{~s}]$

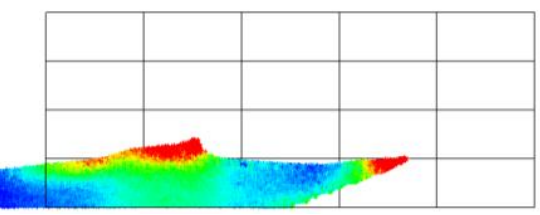

$\mathrm{T}=7.5[\mathrm{~s}]$

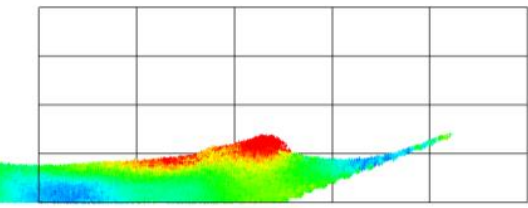

$\mathrm{T}=10.0[\mathrm{~s}]$

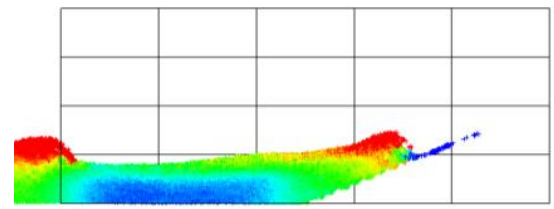

$\mathrm{T}=12.5[\mathrm{~s}]$

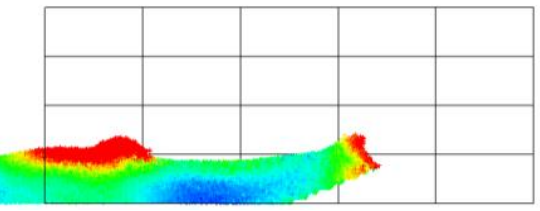

$\mathrm{T}=15.0[\mathrm{~s}]$

a) 参照解

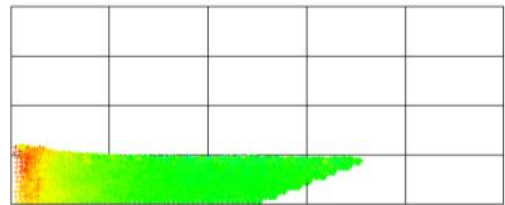

$\mathrm{T}=2.5[\mathrm{~s}]$

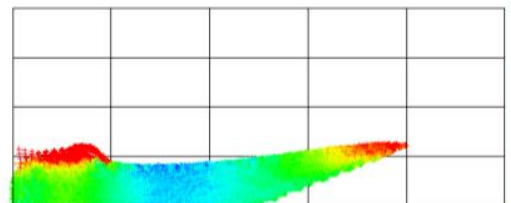

$\mathrm{T}=5.0[\mathrm{~s}]$

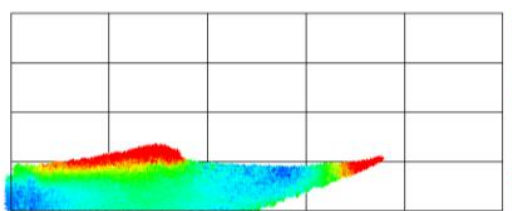

$\mathrm{T}=7.5[\mathrm{~s}]$

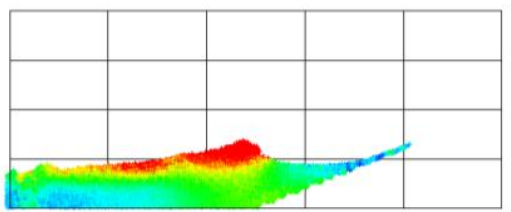

$\mathrm{T}=10.0[\mathrm{~s}]$

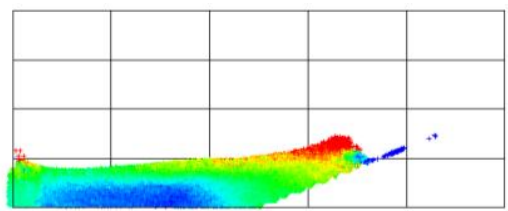

$\mathrm{T}=12.5[\mathrm{~s}]$

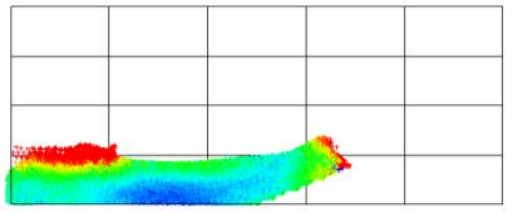

$\mathrm{T}=15.0[\mathrm{~s}]$

b) 提案法

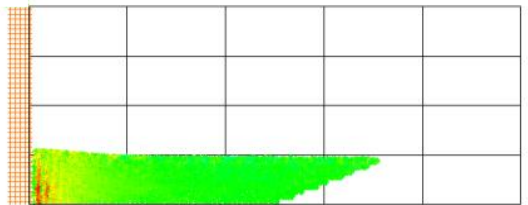

$\mathrm{T}=2.5[\mathrm{~s}]$

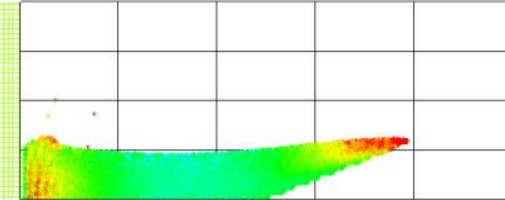

$\mathrm{T}=5.0[\mathrm{~s}]$

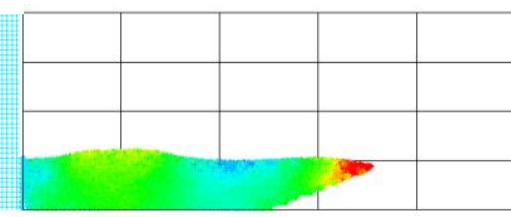

$\mathrm{T}=7.5[\mathrm{~s}]$

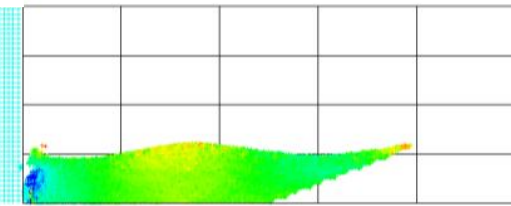

$\mathrm{T}=10.0[\mathrm{~s}]$



$\mathrm{T}=12.5[\mathrm{~s}]$

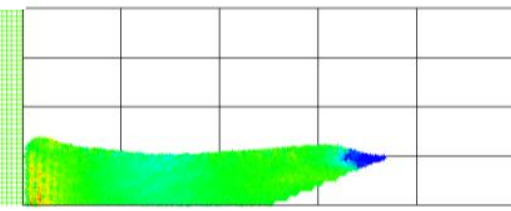

$\mathrm{T}=15.0[\mathrm{~s}]$

c) 従来法 $[\mathrm{m} / \mathrm{s}]$

$-1.0$

$-0.5$

0.0

0.5

1.0

図-10 解析結果（長周期波）（コンター $\mathrm{x}$ 方向速度）

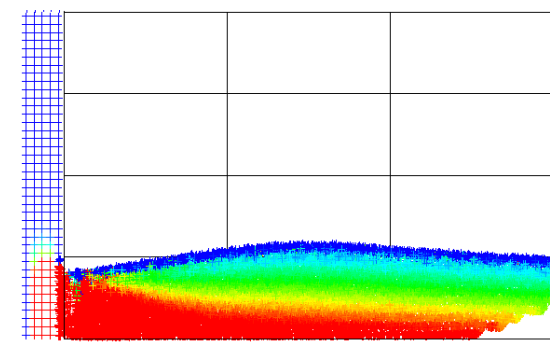

$\mathrm{T}=3.65[\mathrm{~s}]$

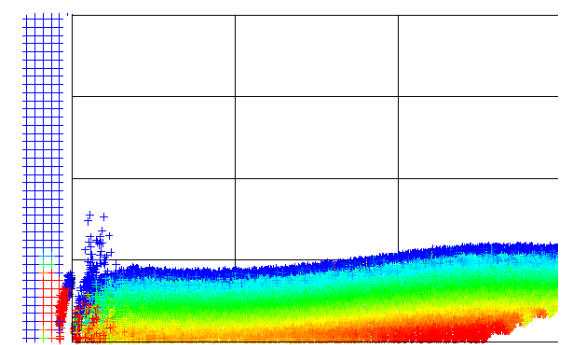

$\mathrm{T}=4.35[\mathrm{~s}]$

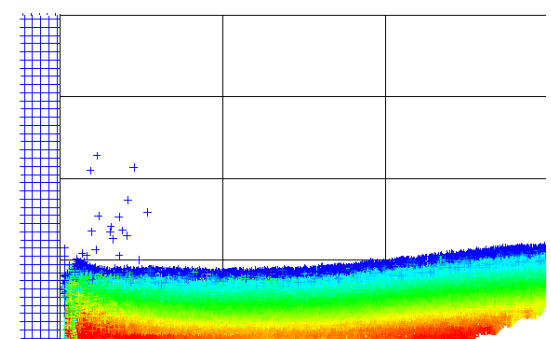

$\mathrm{T}=4.65[\mathrm{~s}]$

$[\mathrm{Pa}]$

$\begin{array}{llllll}0 & 2000 & 4000 & 6000 & 8000 & 10000\end{array}$

図-11 従来法における流入境界での圧力の乱れ（コンター圧力） 


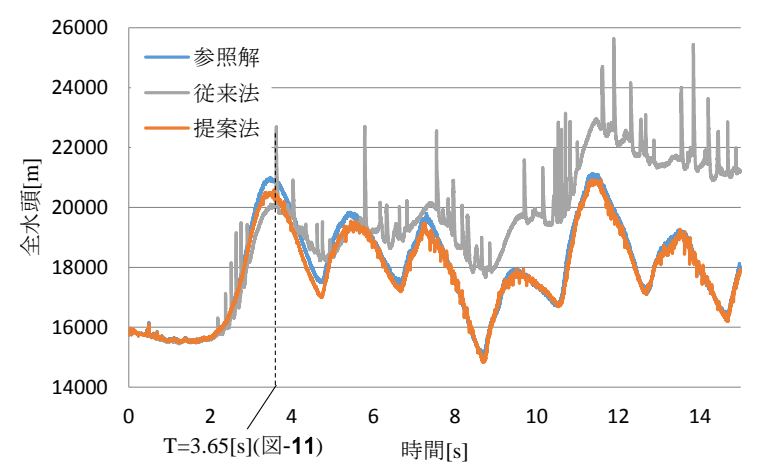

(a)全水頭の時刻変化

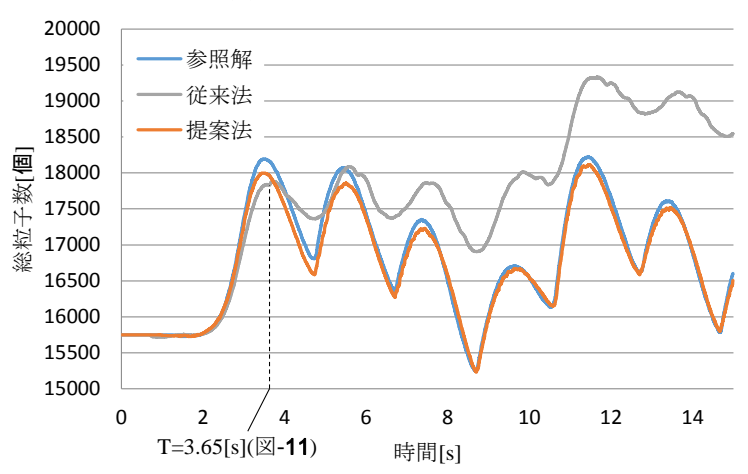

(b)水粒子数の時刻変化

図-12 解析結果（短周期波）

次に，解析間でのエネルギー収支を確認するため に, 図-9の赤枠で囲まれた領域の, 水粒子の全水頭, 粒子数の時刻履歴を比較検証した。 その結果を図12に示す.この結果からも従来法では, 引き波の 際に水粒子が仮想造波板と反発し合うことにより, 十分な水粒子の吸収を行うことができず，時間の経 過とともに水粒子が増加していることが確認できる. また, 従来法における全水頭の振動は, 境界付近の 圧力の乱れが発生する時刻と一致している。一方で, 提案法では流速分布と同様に参照解の全水頭, 総粒 子数と良好な一致が見られた。このことから，押し 波と引き波が繰り返され, 水深方向に流速分布が存 在する波を連成する場合においても提案手法の有用 性が示された。

上記の比較では，仮想造波板と遷移領域I，IIの両 者を設けた流入セルの有用性を確認した。以下には, 高精度化につながった要因を検証するために, 遷移 領域Iのみ, あるいはIIのみを設けた場合と提案法を 比較することにした. case1は20列の境界処理用セ ル（遷移領域I, IIの両者を含む）を用いた提案法， case2 25 列の遷移領域 I のみ仮想造波板の横に配置 したもの, case3は5列の遷移領域 II のみを配置し， case4は遷移領域を配置せず仮想造波板のみを用い た場合とする（図-13を参照）。図-9の赤枠で囲ま れた領域の全水頭, 粒子数を図-14に示寸. 遷移領 域を配置しないcase4は, 従来法と同様に時刻の経 過とともに粒子数が増加していることから, 遷移領 域の存在が，仮想造波板と流出する水粒子の反発を

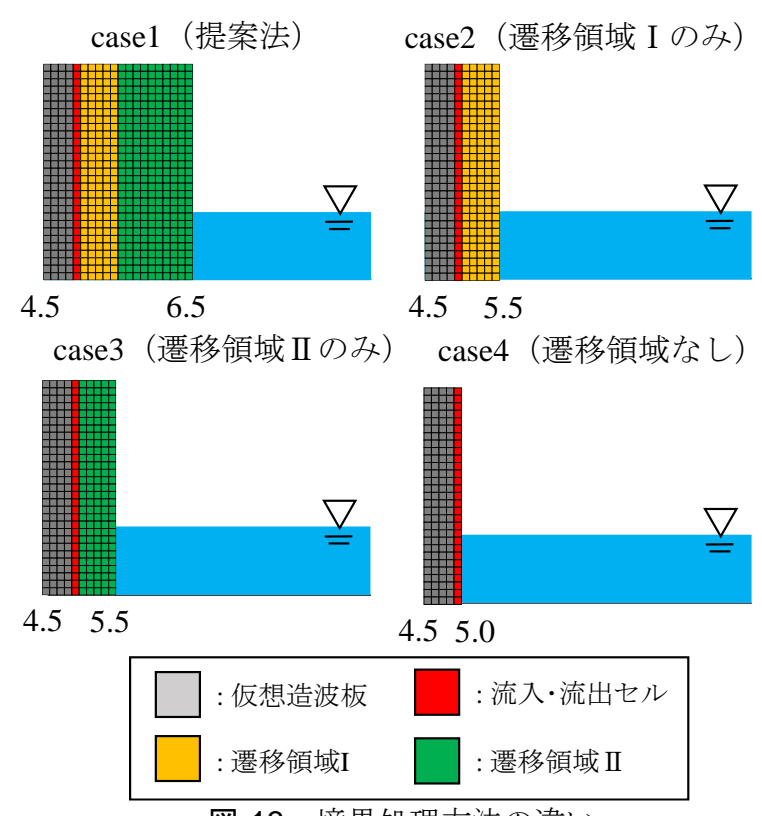

図-13＼cjkstart境界処理方法の違い

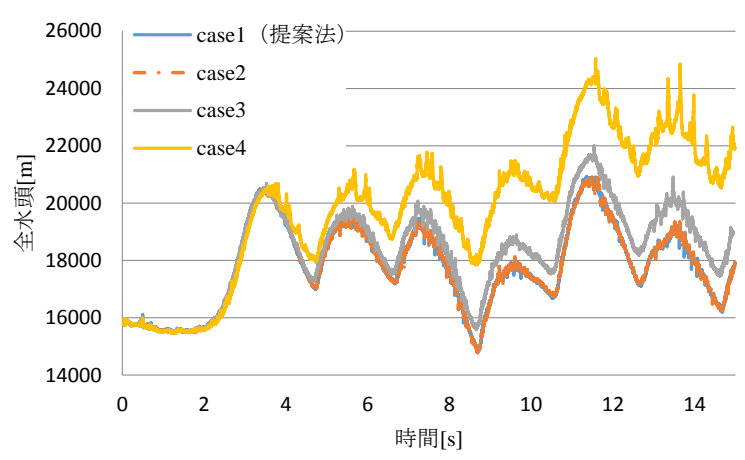

(a)全水頭の時刻変化

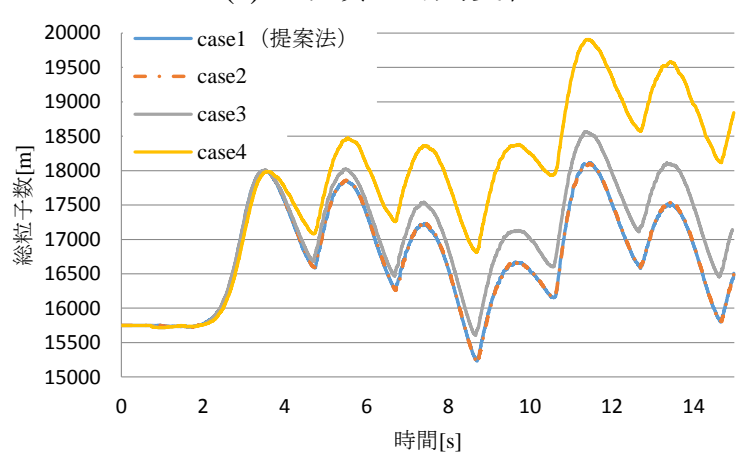

(b)水粒子数の時刻変化

図-14 解析結果（短周期波）

緩和する役割を果たすことがわかる，次に遷移領域 IIのみを5列設けたcase3は, case2 と比較して提案手 法との差異が生じていることが確認された。このこ とから, 流入・流出境界セルの近傍に強制的に圧力 を付与寸る遷移領域 I の有用性が示された。一方で, 遷移領域 II を設けないcase2は, 提案手法との差異 がほぼ見られなかった。 セル領域と解析領域の境界 を見ると（図-15を参照）， case2において参照解と 異なる圧力分布を示しており, 遷移領域 II の存在に 


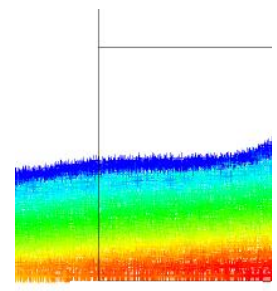

a) 参照解

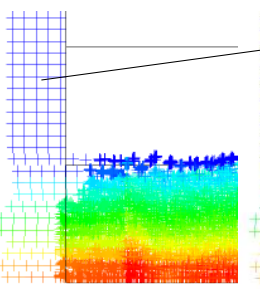

b) 提案法(case1)

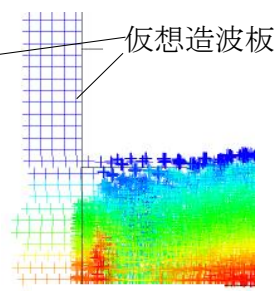

c) case 2

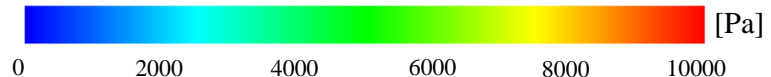

図-15 流入境界付近の圧力分布 $(\mathrm{T}=8.2[\mathrm{~s}])$

より，圧力の乱れを緩和させていることが確認でき た。しかしながら, 提案手法においても遷移領域と 解析領域との圧力の間にギャップが生じていおり, これは, 進行速度が異なる遷移領域と解析領域の間 で水粒子の粗密が生じ，非圧縮条件緩和型ソース項 の2項目が過剩に評価されていることが原因である と考えられる. 仮想造波板近傍の圧力を滑らかに付 与寸るため, 今後さらなる改善が必要であろう.

\section{5. まとめと今後の課題}

多段階ズーミング津波解析に向けた各解析間の連 成手法の検討として, マトリックスアレイ状の仮想 造波板と 2 種類の遷移領域により構成される境界処 理用セルを用いた境界処理法を提案した。 長波の押 し波を模した検証例題では, 2次元解析によって得 られた断面平均流速を用いた従来型の境界処理法で もある程度の精度で再現できるものの, 提案手法に より更なる高精度化が実施できることを示した．次 に, 継続する短周期の押し波, 引き波を模した検証 例題では，水深方向に流速分布を持つ波の連成にお ける従来手法の問題点を明確にし, 提案手法の一例 である高さ方向一様仮想造波板の有用性を示した。 加えて, 2種類の遷移領域の必要性を示した。 なお, 今回の例題では低解像度と高解像度に相当する低レ ベル解析と高解像度解析は同一の解析手法を用いて いるため, 両者の境界間では矛盾のない情報を伝達 できている.しかし, 今後ズーミング解析として応 用した際には, 両者の境界において差が生じること も予想される. 特に双方向解析においてはこの矛盾 の解消方法が必要となるものと予測する. また今後 は，より実務的な例題（実地形モデルを用いた津波 遡上問題など）にいても本手法の妥当性を示し. マ トリックスアレイ状仮想造波板の適用範囲の拡大を 目指寸.

\section{参考文献}

1) 高瀬慎介, 加藤準治, 森口周二, 寺田賢二郎, 京谷 孝史, 野島和也, 桜庭雅明, 樫山和男: 安定化有限 要素法を用いた 2D-3D ハイブリット手法による津波 解析, 土木学会論文集 A2(応用力学),70(2), 307-315, 2014

2) 本橋英樹, 野中哲也, 中村真貴, 原田隆典, 坂本佳 子：広域 3 次元シミュレーションにおける造波境界 の設定方法, 土木学会論文集 B2(海岸工学), 70(2), I_181-I_185,2014

3）室谷浩平，越塚誠一，金山寛，安重晃，藤沢智光， 玉井祐，柴田和也，三目直登，吉村忍：津波波源加 ら浅水波方程式を用いて生成した入力境界条件によ る MPS 法市街地遡上解析, 日本機械学会 第 26 回計 算力学講演会（CMD2013）

4) 諏訪多聞, 今村文彦, 菅原大助: 非線形長波モデル と流体粒子法による津波シミュレータの開発，土木 学会論文集 B2(海岸工学) 70(2),II16-I_20,2014

5）柴田和也，室園浩司，越塚誠一，酒井幹夫，玉井祐， 市東素明，倉田隼次：重合粒子法の開発および海水 打ち込みと津波一の適用, 日本船舶海洋工学会講演 会論文集, 第 14 号, 論文番号 2012S-G2-9, pp.215218,2012

6) 柴田和也, 越塚誠一, 室園浩司：重合粒子による粒 子法の計算コスト削減手法の改良, 計算工学講演会 論文集, Vol. 18, 2013

7) J. P. Morris, P. J. Fox and Y. Zhu, Modeling Low Reynolds Number Incompressible Flows Using SPH, Journal of Computational Physics, Vol.136, pp. 214-226, 1997.

8) J. J. Monaghan, J. C. Lattanzio, A refined particle method for astrophysical problems, Astronomy and Astrophysics, 149:135-143,1985

9) E. S. Lee, C. Moulinec, R. Xu, D. Violeau, D. Laurence and P. Stansby, Comparisons of weakly compressible and truly incompressible algorithms for the SPH mesh free particle method, Journal of Computational Physics, Vol.227(18), pp.8417-8436, 2008.

10) S.J. Lind, R. Xu, P.K. Stansby, B.D. Rogers, Incompressible smoothed particle hydrodynamics for free-surface flows, A generalized diffusion-based algorithm for stability and validations for impulsive flows and propagating waves, J. Compt. Phys. 231 (4), 1499-1523, 2012.

11) Mitsuteru Asai, Abdelraheem M. Aly, Yoshimi Sonoda and Yuzuru.Sakai, A stabilized incompressible SPH method by relaxing the density invariance condition, InternationalJournal for Applied Mathematics, Volume, Article ID 139583, 24 pages, 2012

12) S. Marrone, M. Antuono, A. Colagrossi, D. Le Touze, G. Graziani, $\delta$-SPH model for simulating violent impact flows, Omput. Methods Appl. Mech. Engrg. 200 15261542,2011

13) 浅井光輝, 藤本啓介, 田邊将一, 別府万寿博 : 階段 状の非適合境界を有する粒子法解析における仮想マ 一カーを用いたすべり・非すべり境界処理法, 計算 工学論文集, No.20130011, 2013. 04.

(2015. 6. 23受付) 


\section{DEVELOPMENT OF A MATRIX ARRAY SHAPED VIRTUAL WAVE-MAKING PLATE FOR MULTI-ZOOMING TSUNAMI SIMULATION BASED ON THE PARTICLE METHOD}

\section{Yoshiya MIYAGAWA and Mitsuteru ASAI}

A simulation tool which can predict possible damages to the structures in coastal area plays decisive roles to mitigate and prevent next huge tsunami. According to the previous researches on the analysis of tsunami, two-dimensional shallow water simulation have been developed to project tsunami height and tsunami arrival times, as well as threedimensional analysis have been utilized to evaluate tsunami fluid force in local scale. The authors have developed multi-zooming tsunami simulation having both advantages of two-dimensional tsunami analysis (finite difference method) and three-dimensional tsunami analysis (particle method). However there are no boundary treatments which can manipulate measured values in each analysis with high accuracy. In this study, matrix array shaped virtual wave-making plate was suggested as a boundary treatment method for multi-zooming tsunami simulation by using particle method. Limitation of application of previous scheme was described based on two validation problems. Besides we confirmed that complicated velocity distribution can be replicated correctly using suggested method. 